\title{
Translationally Controlled Tumour Protein (TCTP) is present in human cornea and increases in herpetic keratitis
}

\author{
Cinzia Batisti ${ }^{1 \dagger}$, Maria R Ambrosio ${ }^{2 * \dagger}$, Bruno J Rocca ${ }^{2}$, Gian M Tosi ${ }^{1}$, Jean C Sanchez ${ }^{3}$, Felice Arcuri ${ }^{2}$, \\ Marcella Cintorino ${ }^{2}$ and Sergio A Tripodi ${ }^{2}$
}

\begin{abstract}
Background: Translationally Controlled Tumour protein is a multifunctional calcium binding protein which has an important role in apoptosis, calcium levels balance and immunological response. The aim of this study was to evaluated the presence and distribution of TCTP in healthy human corneas and to identify and characterize the presence and distribution of this protein in human normal cornea. Since recent studies suggest that apoptosis, calcium levels and immunological mechanisms play a role in the pathogenesis of herpetic stromal keratitis, we studied TCTP expression in this disease.
\end{abstract}

Methods: We evaluated the expression of TCTP at both RNA messanger and protein level by using reverse transcriptase analysis, immunoblotting and immunohistochemistry in 10 healthy samples cornea: four obtained after penetrating keratoplasty and six from eyes enucleated for other pathologies. Finally, we analysed by immunohistochemistry ten paraffin-embedded samples of Herpes simplex virus keratitis collected at Siena Department of Human Pathology and Oncology: 5 had clinically quiescent disease and 5 had active corneal inflammation.

Results: Reverse transcriptase and immunoblotting demonstrated TCTP expression in cornea as a 22,000 Da molecular weight band corresponding to the molecular weight of this protein. Immunohistochemically, all the layers of normal corneal epithelium showed TCTP cytoplasmic expression. TCTP was, also, observed in keratocytes and in the endothelium. In Herpes simplex virus keratitis samples, strong expression of TCTP was evident in stromal cells, in the inflammatory infiltrate and in neo-vessels.

Conclusions: In this preliminary study we demonstrated, for the first time, the presence of TCTP in human cornea, suggesting a potential role in the pathogenesis of herpes virus keratitis.

Virtual Slides: The virtual slide(s) for this article can be found here: http://www.diagnosticpathology.diagnomx.eu/ vs/33068134477428149

\section{Background}

Translationally controlled tumour protein (TCTP), also known as fortilin [1] or TPT1 [2] is a ubiquitously expressed protein of $21 \mathrm{kDa}$ in mice and $23 \mathrm{kDa}$ in humans, expressed in all eukaryotes. It bears no sequence similarity with any other known protein [1]. It is encoded by a gene that maps to chromosome 13q14.13

\footnotetext{
* Correspondence: maradot@libero.it

${ }^{\dagger}$ Equal contributors

${ }^{2}$ Department of Human Pathology and Oncology, Anatomical Pathology

Section, University of Siena, via delle Scotte 6, 53100, Siena, Italy

Full list of author information is available at the end of the article
}

$[1,3]$ and its expression is highly regulated at transcriptional and translational level and by a wide range of extracellular signals. Its name originates from the observation that TCTP transcripts accumulate in resting cells and are rapidly translated into the protein when the cells require it [4]. Although TCTP was first considered a tumour protein [5], its expression is not limited to cancer, as it has been found in normal cells and tissues [6]. Since its discovery by Yenofsky [7], it has become clear that TCTP is a multifaceted protein, implicated in many biological processes and exerting biological activity at

\section{Biomed Central}

(c) 2012 Batisti et al.; licensee BioMed Central Ltd. This is an Open Access article distributed under the terms of the Creative Commons Attribution License (http://creativecommons.org/licenses/by/2.0), which permits unrestricted use, distribution, and reproduction in any medium, provided the original work is properly cited. 
extracellular and intracellular level [4]. TCTP participates in cell growth, cell cycle progression, division and proliferation [8]. An anti-apoptotic function of TCTP in human cancer cells has also been identified. This function may be related to calcium binding [9-12] and inhibition of Bax dimerization [4]. The interaction between TCTP and p53 prevents apoptosis by destabilizing p53 [13]. TCTP is also considered a heat shock protein with chaperone-like activity [14]. It functions as an IgEdependent histamine releasing factor, having cytokinelike activity in acute allergic response and being involved in immunological response [15]. Association with a cytoskeletal component, F-actin, and a role in cell shape regulation were also recently discovered [16], as well as its capacity to bind tubulin and serve as a substrate for Polo-like kinase 1 (Plk-1) [4].

Ocular vision depends on corneal transparency and shape. These properties depend on the balance between cell proliferation and apoptosis, both mechanisms regulated by TCTP [17]. The presence and distribution of TCTP in the human cornea has not yet been fully analysed. Studies in the literature have used proteomic techniques and been limited to cultured keratocytes [18]. Here we evaluated the presence and distribution of TCTP in healthy human corneas for the first time by immunoblotting, reverse transcriptase analysis and immunohistochemistry. Since recent studies suggest that apoptosis [19], calcium levels [20] and immunological mechanisms [21] play a role in the pathogenesis of herpetic stromal keratitis (HSK), we studied TCTP expression in this disease.

\section{Materials and methods}

\section{Ethics Statement}

Ethics approval for this study was obtained from the Institutional Review Board at the University of Siena (Italy). Informed written consent was obtained in all cases.

\section{Patients}

We used 10 samples of healthy corneal tissue, four obtained after penetrating keratoplasty (PKP) and six from eyes enucleated for retinoblastoma, in which the anterior segment was tumor-free. Ten other corneal tissue samples were collected from patients undergoing PKP for sequelae of HSK. The diagnosis of HSK was based on clinical and slit lamp findings. PKPs were performed consecutively from August 2010 to December 2011.

\section{Tissue preparation}

The surgical specimens obtained after PKP were grossly examined and halved (Figure 1A-B). Half of the samples were rinsed in sterile HBSS (Hanks balanced salt solution) at room temperature, blotted dry and dissected

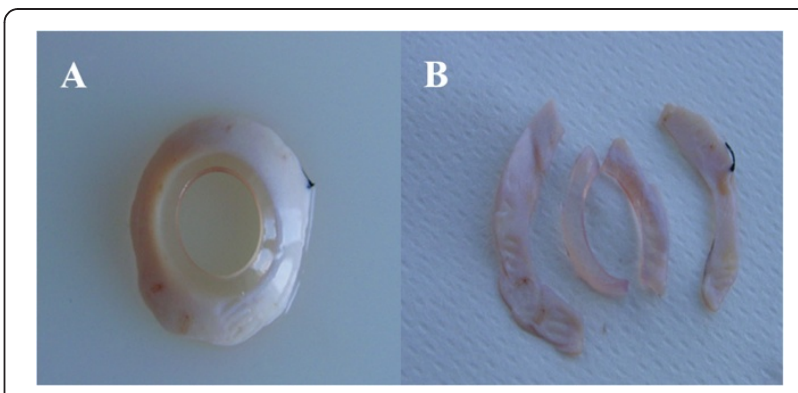

Figure 1 A-B. The surgical specimen. Peripheral corneal tissue obtained after penetrating keratoplasty.

with a razor blade. To analyse protein and RNA, they were snap-frozen and stored in liquid nitrogen. The other half were fixed in $10 \%$ buffered formalin and embedded in paraffin. From paraffin-embedded blocks of PKP and enucleation samples, 4- $\mu$ m-thick sections were obtained and processed for histology and immunohistochemistry. Anti-human TCTP mouse monoclonal antibody was prepared as previously described [22].

\section{Western blot analysis}

Frozen corneal tissue samples were thawed, reduced to small pieces with a razor blade and homogenized on ice with a Polytron blender (Kinematica, Lucerne, Switzerland) in lysis buffer [ $50 \mathrm{mMTris}-\mathrm{HCl}, 5 \mathrm{mM}$ magnesium acetate, 0.2 mM EDTA, 0.5 mMdithiothreitol, 10\% (vol/vol) glycerol, 0.2\% (vol/vol) Triton X-100 ( $\mathrm{pH} \mathrm{7.5)]}$ supplemented with a protease-inhibitor cocktail (Sigma Chemical Co, Milan-Italy), three times for 20 seconds each. Tissues were centrifuged at $750 \times \mathrm{g}$ for $10 \mathrm{~min}$ at $4^{\circ}$ $\mathrm{C}$ and the supernatant assayed for total protein content and stored at $-80^{\circ} \mathrm{C}$. Western blot analysis was carried out as previously described [23].

\section{Detection of TCTP mRNA}

Total RNA was extracted using the method of Chomczynski and Sacchi. Frozen tissues were crushed with a pestle and homogenized in Tri-Reagent (Life Technologies, Monza-Italy) with a Polytron blender (Kinematica, Luzern-Switzerland). Cell pellets were thawed and immediately lysed with Tri-Reagent. RNA extraction was carried out as recommended by the manufacturer. TCTP mRNA was detected by reverse transcriptase-polymerase chain reaction (RT-PCR) as previously described [23]. The products were separated by $2.0 \%$ agarose gel electrophoresis, visualized by ethidium bromide staining, and photographed.

\section{Immunohistochemical analysis}

Immunohistochemistry was performed using the alkaline phosphatase-anti-alkaline-phosphatase (APAAP) method. Sections were dewaxed, rehydrated and washed in Tris- 
buffered saline [TBS, 20 mMTris- $\mathrm{HCl}, 150 \mathrm{mMNaCl}$ (pH 7.6)]. Antigen retrieval was carried out by incubating sections in sodium citrate buffer $(10 \mathrm{mM}, \mathrm{pH}$ 6.0) in a microwave oven at $750 \mathrm{~W}$ for $5 \mathrm{~min}$. Sections were incubated with an anti-human TCTP monoclonal antibody diluted 1:100 in TBS overnight at $4^{\circ} \mathrm{C}$. Slides were washed and incubated for $30 \mathrm{~min}$ with a rabbit anti-mouse antibody (Dako, Milan, Italy, dilution 1:30) and finally incubated for 30 min with APAAP complex (Dako, dilution 1:50) in TBS. The alkaline phosphatase reaction was detected using fuchsin and naphthol. TCTP expression was evaluated semiquantitatively by HSCORE, as previously described [24]. Placental tissue served as external positive control [10].

\section{Statistical analysis}

Statistical analysis was performed using a statistical software package (SYSTAT-7). Differences in TCTP pattern between cases grouped according to inflammation and neovascularization (groups 1 and 2) were analysed using the Chi-square test and Fisher's exact test. Statistical significance was set at $P \leq 0.05$.

\section{Results}

\section{Normal cornea}

\section{RT-PCR analysis of TCTP MRNA levels}

To evaluate steady-state levels of TCTP mRNA, total RNA extracted from tissues was examined by RT-PCR. When amplification was carried out in the presence of human TCTP primers, an intense band corresponding to the TCTP product was obtained on the agarose gel from the cDNA of each corneal tissue specimen (Figure 2).

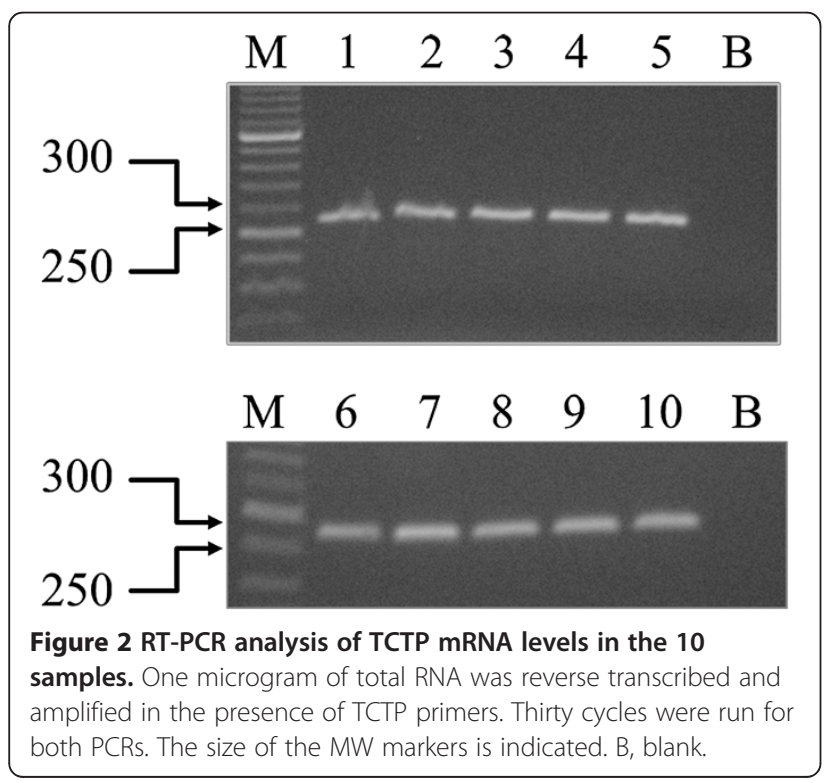

\section{Western blot analysis}

To further confirm the presence of TCTP in our specimens, Western blot analysis was carried out. After fractionation on SDS-PAGE, proteins of all specimen homogenates were blotted onto nitrocellulose and the filter exposed to an anti-TCTP antibody. A single band of the approximate molecular weight (MW) of 22,000 Da was detected in all specimens (Figure 3). Staining was abolished by probing blots identical to those described above with the antibody pre-absorbed with recombinant TCTP. Control tissue was represented by placenta, as previously described [10].

\section{Immunohistochemistry}

Immunohistochemical analysis performed with the antiTCTP antibody showed cytoplasmic staining. TCTP expression was observed in the basal (Figure 4A) and intermediate (Figure 4B) cell layers of corneal epithelium with HSCOREs of 2 and 1, respectively. TCTP was also evident in keratocytes and endothelial cells with a HSCORE of 1 (Figure 4B, inset).

\section{HSK}

Of the 10 specimens from patients with HSK, 5 had active keratitis (moderate to severe inflammation and neovascularization) and 5 had quiescent disease (absent or mild inflammation). In the active HSK samples, intense and diffuse (HSCORE 3) TCTP staining was observed in stromal cells throughout all layers of the corneal

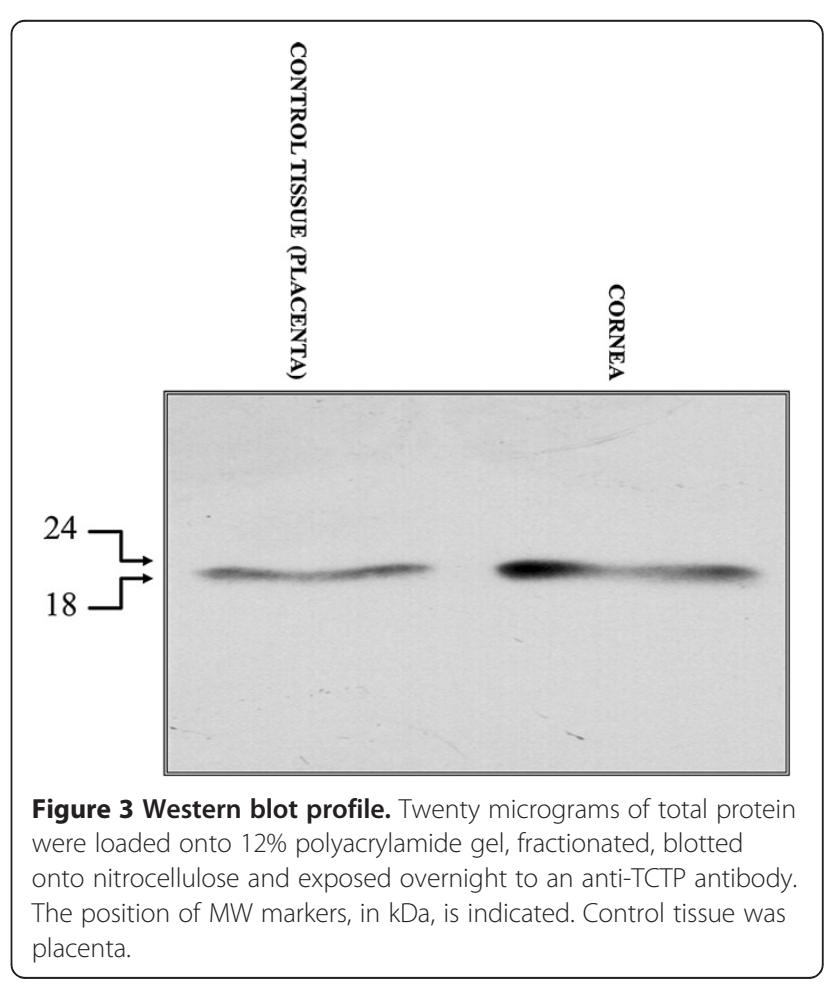




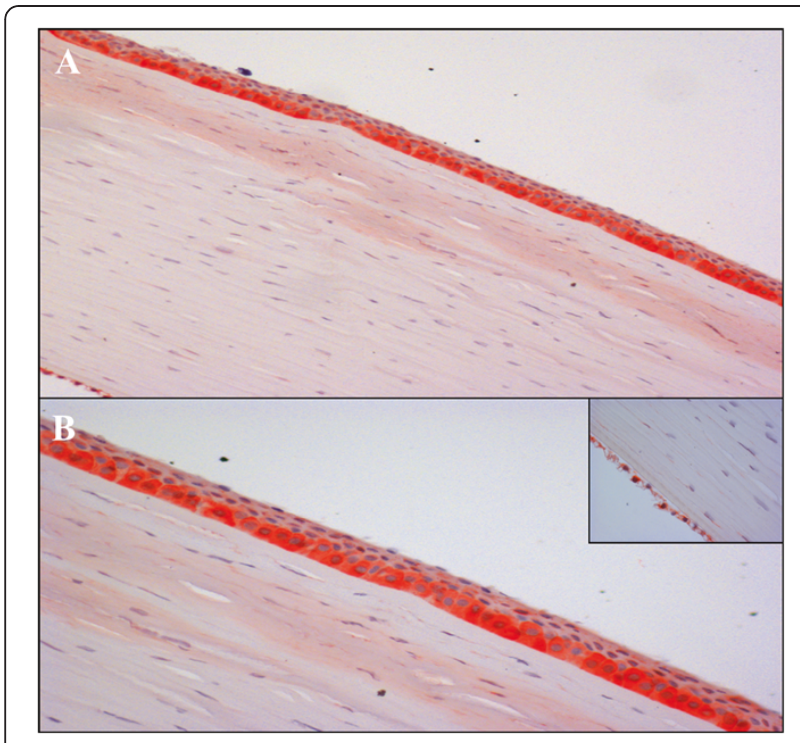

Figure $\mathbf{4}$ Immunohistochemical profile of healthy corneal tissue. Positive TCTP staining was observed in the basal and intermediate cell layers of the corneal epithelium (A-B); weak and focal staining was observed in keratocytes and along the endothelial cell layer (B, inset) $[A$, original magnification (O.M) 2.5x; B, O.M. 5x; inset, O.M. 2.5x].

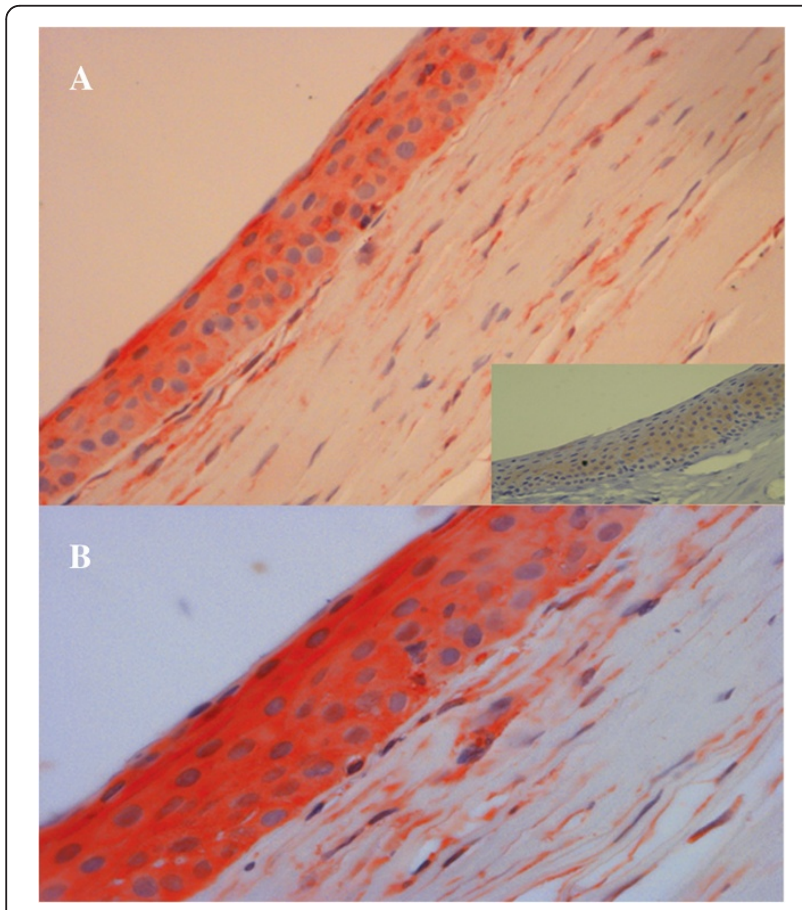

Figure 5 Immunohistochemical profile of corneal tissue with HSK. In active keratitis, strong TCTP staining was observed throughout all layers of the corneal epithelium, as well as in stromal cells (A-B), whereas in quiescent disease little or no expression was present (A, inset) [A, O.M 10x; B, O.M. 20x; inset, O.M. 20x]. epithelium (Figure 5A-B). In the quiescent disease samples, TCTP expression was weak (HSCORE 1), present only in corneal epithelium with little or no immunohistochemical expression in the stroma (Figure 5A, inset) $(\mathrm{p}=0.001)$.

\section{Discussion}

TCTP is a highly conserved, ubiquitously expressed protein involved in multiple biological activities, including apoptosis [13]. An extensive review of the literature showed that previous studies on TCTP in the cornea used proteomics techniques were limited to cultured keratocytes [18]. In the present study we demonstrated the presence of TCTP in human corneal tissue by RTPCR and immunoblotting, and confirmed these findings by immunohistochemistry using an antibody against TCTP. Since apoptosis plays a key role in HSK and is controlled by TCTP, we also attempted to find a pathogenic correlation between TCTP and HSK, evaluating TCTP expression in corneal samples with HSK. TCTP inhibited the proapoptotic proteins Bax and BCLxL, promoters of membrane attack complex (MAC) pore formation via dimerization of the mitochondrial membrane. TCTP inserts itself in the mitochondrial membrane, preventing Bax from dimerizing. This inhibits MAC pore formation and prevents any flux of apoptosis promoting factors into the cell. TCTP also binds to Mcl1 , stabilizing it and enhancing its anti-apoptotic activity. In addition, TCTP was shown to bind p53 and prevent apoptosis by destabilizing the protein and repressing transcription of p53 [4]. A correlation was found between the degree of inflammation and expression of TCTP in corneal epithelium, as well as in inflammatory infiltrate in HSK patients with active disease [25]. In the case of mild inflammation, we found low expression of TCTP, limited to neovessels and keratinocytes. These results suggest a double role of TCTP in herpes keratitis: as an antiapoptotic protein in corneal cells and as a cytokine-like protein in the stroma, where TCTP may be secreted by inflammatory cells, probably monocytes, in the extracellular milieu. Apoptosis has been shown to limit viral invasion: corneal infection with wild-type virus results in apoptosis of a number of infected epithelial cells [26]. Primary herpes simplex virus-1 (HSV-1) corneal infection stimulates apoptosis of anterior keratocytes in the stroma underlying the site of epithelial injury. TCTP may modulate the keratocyte apoptotic response, limiting stromal damage as well as triggering the keratocyte apoptotic response via soluble mediators released by epithelial injury secondary to corneal HSV-1 infection. Considering the importance of apoptosis as a general mechanism for eliminating normal and pathologically altered cells, manipulation of apoptosis may offer new possibilities for treating HSK. 
We also found a huge amount of TCTP in the extracellular stroma of actively inflamed HSK, which is in line with previous studies on broncho-alveolar lavage fluids of patients with eosinophilic pneumonia and asthma $[27,28]$. A mechanism by which extracellular TCTP might intervene through cytokine-like activity in the complex pathogenesis of HSK is by regulating the immune-mediated response to herpes simplex virus. In fact, HSK is currently thought to be an immunemediated disease. CD4 positive Th1 cells are involved in the development of inflammatory HSK corneal lesions: infiltration of CD4 positive Th1 cells into the cornea causes release of cytokines, mainly interleukin (IL)-2 and interferon (IFN) $-\gamma$, which elicit an inflammatory response and recruit neutrophils and macrophages. TCTP is known to inhibit the release of IL-2 in human peripheral blood $\mathrm{T}$ cells and Jurkat $\mathrm{T}$ cells [29] and a role of TCTP in the modulation of $\mathrm{T}$ regs apoptosis/survival was recently demonstrated [30].

Repair of damage after each infection progressively impairs the biomechanical properties of the cornea. The repair process or wound healing of corneal epithelium is complex, including cell migration, proliferation and differentiation, all of which depend on calcium-mediated signals [31]. Calcium concentrations vary during wound healing, thus inducing variations in cell motility, morphology and adhesion that are all essential to the process [32]. Calcium levels are regulated by TCTP [6].

\section{Conclusions}

In this study we demonstrated the presence and distribution of TCTP in human corneal tissue and its expression in HSK, probably related to inflammation and neovascularization. These findings suggest a multifunctional role of TCTP in corneal wound healing, HSV-1 corneal infection, IgE-mediated hypersensitivity reactions and maintenance of corneal transparency and shape [16] by interaction with cytoskeletal proteins. Further in vivo and in vitro studies are needed to fully understand the pathophysiological roles of TCTP in corneal diseases, considering that only 20 samples were tested for TCTP and that no data on its role in HSK and other types of keratitis are available in the literature. Since a series of pharmaceutical compounds decrease TCTP expression by down-regulation of its expression at protein level, broader studies may help to determine whether TCTP may act as a target for drugs, contributing to new alternatives for the treatment of HSK, avoidance of complications and reduction of relapses [33].

\section{Abbreviations}

TCTP: Translationally controlled tumour protein; PLK1: Polo-like kinase 1; HSK: Herpes stromal keratitis; PKP: Penetrating keratoplasty; HBSS: Hanks balanced salt solution; RT-PCR: Reverse transcriptase-polymerase chain reaction; APAAP: Alkaline phosphatase-anti-alkaline-phosphatase; TBS: Tris- buffered saline; MAC: Membrane attack complex; HSV-1: Herpes simplex virus-1; IL: Interleukin; IFN: Interferon; MW: Molecular weight.

\section{Competing interest}

The authors declare that they have no competing interests.

\section{Authors' contributions}

CB and MRA wrote the paper; BJR analysed the histological and immunohistochemical sections; FA conducted the molecular biology experiments; GMT acquired clinical data; JCS contributed reagents; MC contributed his expertise and fruitful discussion; SAT coordinated the work and gave final approval of the version to be published. All authors read and approved the final manuscript.

\section{Author details}

${ }^{1}$ Departments of Ophthalmology, University of Siena, Siena, Italy. ${ }^{2}$ Department of Human Pathology and Oncology, Anatomical Pathology Section, University of Siena, via delle Scotte 6, 53100, Siena, Italy. ${ }^{3}$ Geneva Proteomics Center, Central Clinical Chemistry Laboratory, Geneva University Hospital, Geneva, Switzerland.

Received: 3 June 2012 Accepted: 19 July 2012

Published: 1 August 2012

\section{References}

1. Li F, Zhang D, Fujise K: Characterization of fortilin, a novel antiapoptotic protein. J BiolChem 2001, 276:47542-47549.

2. Fiucci G, Lespagnol A, Stumptner-Cuvelette $P$, Beaucourt S, Duflaut D, Susini $L$, Amson R, Telerman A: Genomic organization and expression of mouse Tpt1 gene. Genomics 2003, 81:570-578.

3. Zhang D, Li F, Weidner D, Mnjoyan ZH, Fujise K: Physical and functional interaction between myeloid cell leukemia 1 protein (MCL1) and fortilin. The potential role of MCL1 as a fortilin chaperone. J BiolChem 2002, 277:37430-37438.

4. Susini L, Besse S, Duflaut D, Lespagnol A, Beekman C, Fiucci G, Atkinson AR, Busso D, Poussin P, Marine JC, Martinou JC, Cavarelli J, Moras D, Amson R, Telerman A: TCTP protects from apoptotic cell death by antagonizing Bax function. Cell Death Differ 2008, 15:1211-1220.

5. Rao KV, Chen L, Gnanasekar M, Ramaswamy K: Cloning and characterization of a calcium-binding, histamine releasing protein from Schistosomamansoni. J Bio/Chem 2002, 277:31207-31213.

6. Arcuri F, Papa S, Carducci A, Romagnoli R, Liberatori S, Riparbelli MG, Sanchez JC, Tosi P, del Vecchio MT: Translationally controlled tumor protein (TCTP) in the human prostate and prostate cancer cells: expression, distribution, and calcium binding activity. Prostate 2004, 60:130-140.

7. Yenofsky R, Cereghini S, Krowczynska A, Brawerman G: Regulation of mRNA utilization in mouse erythroleukemia cells induced to differentiate by exposure to dimethyl sulfoxide. Mol Cell Biol 1983, 3:1197-1203.

8. Bommer UA, Thiele BJ: The translationally controlled tumour protein (TCTP). Int J Biochem Cell Biol 2004, 36:379-385.

9. Gachet $Y$, Tournier S, Lee M, Lazaris-Karatzas A, Poulton T, Bommer UA: The growth-related, translationally controlled protein $\mathrm{P} 23$ has properties of a tubulin binding protein and associates transiently with microtubules during the cell cycle. J Cell Sci 1999, 112:1257-1271.

10. Arcuri F, Papa S, Meini A, Carducci A, Romagnoli R, Bianchi L, Riparbelli MG, Sanchez JC, Palmi M, Tosi P, Cintorino M: The translationally controlled tumor protein is a novel calcium binding protein of the human placenta and regulates calcium handling in trophoblast cells. BiolReprod 2005, 73:745-751

11. Kim M, Jung $Y$, Lee $K$, Kim C: Identification of the calcium binding sites in translationally controlled tumor protein. Arch Pharm Res 2000, 23:633-636.

12. Graidist $P$, Yazawa $M$, Tonganunt $M$, Nakatomi $A$, Lin CC, Chang JY, Phongdara A, Fujise K: Fortilin binds Ca2+ and blocks Ca2+-dependent apoptosis in vivo. Biochem J 2007, 408:181-191.

13. Rho SB, Lee JH, Park MS, Byun HJ, Kang S, Seo SS, Kim JY, Park SY: Antiapoptotic protein TCTP controls the stability of the tumor suppressor p53. FEBS Lett 2011, 585:29-35.

14. Gnanasekar M, Dakshinamoorthy G, Ramaswamy K: Translationally controlled tumor protein is a novel heat shock protein with chaperonelike activity. BiochemBiophys Res Commun 2009, 386:333-337. 
15. Thiele H, Berger M, Skalweit A, Thiele BJ: Expression of the gene and processed pseudogenes encoding the human and rabbit translationally controlled tumour protein (TCTP). Eur J Biochem 2000, 267:5473-5481.

16. Yarm FR: Plk phosphorylation regulates the microtubule-stabilizing protein TCTP. Mol Cell Biol 2002, 22:6209-6221.

17. Tempestini A, Schiavone N, Papucci L, Witort E, Lapucci A, Cutrì M, Donnini M, Capaccioli S: The mechanisms of apoptosis in biology and medicine: a new focus for ophthalmology. Eur J Ophthalmol 2003, 13:S11-S18.

18. Karring $\mathrm{H}$, Thøgersen IB, Klintworth GK, Enghild JJ, Møller Pedersen T: Proteomic analysis of the soluble fraction from human corneal fibroblasts with reference to ocular transparency. Mol Cell Proteomics 2004, 3:660-674.

19. Heiligenhaus A, Mrzyk S, Bauer D, Steul KP: Apoptosis in human nonnecrotizing stromal herpes simplex keratitis. KlinMonbl Augenheilkd 2000, 217:178-182.

20. Gonzalez-Gonzalez LA, Molina-Prat N, Doctor P, Tauber J, de la Maza MT S, Foster CS: Clinical features and presentation of infectious scleritis from herpes virus: a report of 35 cases. Ophtalmology 2012, Epub ahed of print.

21. Shimomura Y, Higaki S: The kinetics of herpes virus on the ocular surface and suppression of its reactivation. Cornea 2011, 30(1):S3-7.

22. Sanchez JC, Schaller D, Ravier F, Golaz O, Jaccoud S, Belet M, Wilkins MR, James R, Deshusses J, Hochstrasser D: Translationally controlled tumor protein: A protein identified in several nontumoral cells including erythrocytes. Electrophoresis 1997, 18:150-155.

23. Arcuri F, del Vecchio MT, de Santi MM, Lalinga AV, Pallini V, Bini L, Bartolommei S, Parigi S, Cintorino M: Macrophage migration inhibitory factor in the human prostate: identification and immunocytochemical localization. Prostate 1999, 39:159-165.

24. Lockwood CJ, Murk WK, Kayisli UA, Buchwalder LF, Huang SJ, Arcuri F, Li M, Gopinath A, Schatz F: Regulation of interleukin-6 expression in human decidual cells and its potential role in chorioamnionitis. Am J Pathol 2010, 177(4):1755-1764.

25. Branco FJ, Fraser NW: Herpes simplex virus type 1 latency-associated transcript expression protects trigeminal ganglion neurons from apoptosis. J Virol 2005, 79:9019-9025.

26. Esaki S, Goshima F, Katsumi S, Watanabe D, Ozaki N, Murakami S, Nishiyama $Y$ : Apoptosis induction after herpes simplex virus infection differs according to cell type in vivo. Arch Virol 2010, 155:1235-1245.

27. Choi S, Min HJ, Kim M, Hwang ES, Lee K: Proton pump inhibitors exert anti-allergic effects by reducing TCTP secretion. PLoS One 2009, 4:e5732.

28. Kim M, Min HJ, Won HY, Park H, Lee JC, Park HW, Chung J, Hwang ES, Lee $\mathrm{K}$ : Dimerization of translationally controlled tumor protein is essential for its cytokine-like activity. PLoS One 2009, 4:e6464.

29. Vonakis BM, Sora R, Langdon JM, Casolaro V, MacDonald SM: Inhibition of cytokine gene transcription by the human recombinant histaminereleasing factor in human T lymphocytes. J Immunol 2003, 171:3742-3750.

30. Xiong Z, Yan Y, Song J, Fang $P$, Yin Y, Yang Y, Cowan A, Wang H, Yang XF: Expression of TCTP antisense in CD25 (high) regulatory T cells aggravates cuff-injured vascular inflammation. Atherosclerosis 2009, 203:401-408.

31. Wilson SE, Chaurasia SS, Medeiros FW: Apoptosis in the initiation, modulation and termination of the corneal wound healing response. Exp Eye Res 2007, 85:305-311.

32. Idone V, Tam C, Goss JW, Toomre D, Pypaert M, Andrews NW: Repair of injured plasma membrane by rapid Ca2 +-dependent endocytosis. J Cell Biol 2008, 180:905-914

33. Tuynder M, Fiucci G, Prieur S, Lespagnol A, Géant A, Beaucourt S, Duflaut D, Besse S, Susini L, Cavarelli J, Moras D, Amson R, Telerman A: Translationally controlled tumor protein is a target of tumor reversion. ProcNat/AcadSci USA 2004, 101:15364-15369.

doi:10.1186/1746-1596-7-90

Cite this article as: Batisti et al:: Translationally Controlled Tumour Protein (TCTP) is present in human cornea and increases in herpetic keratitis. Diagnostic Pathology 2012 7:90.

\section{Submit your next manuscript to BioMed Central and take full advantage of:}

- Convenient online submission

- Thorough peer review

- No space constraints or color figure charges

- Immediate publication on acceptance

- Inclusion in PubMed, CAS, Scopus and Google Scholar

- Research which is freely available for redistribution

Submit your manuscript at www.biomedcentral.com/submit
C Biomed Central 